\title{
PENGARUH SALINITAS BERBEDA TERHADAP RESPON OSMOTIK, REGULASI ION DAN PERTUMBUHAN IKAN SIDAT (Anguilla sp.) FASE ELVER SELAMA MASA AKLIMASI DAN KULTIVASI
}

The Influence of Difference Salinity on Osmotic Response, Ionic Regulation and Growth of Sidat (Anguilla sp.) Elver Phase During Acclimation and Cultivation Period

\author{
Tina Anggun Yuliani, Sutrisno Anggoro*), Anhar Solichin \\ Program Studi Manajemen Sumberdaya Perairan, Jurusan Perikanan \\ Fakultas Perikanan dan Ilmu Kelautan, Universitas Diponegoro \\ J1. Prof. Soedarto, SH, Tembalang, Semarang, Jawa Tengah - 50275, Telp/Fax. +6224 7474698 \\ Email : tinaanggunyuliani@gmail.com
}

\begin{abstract}
ABSTRAK
Salinitas yang sesuai dengan kebutuhan tubuh ikan diperlukan untuk efisiensi penggunaan energi tubuh. Penelitian ini bertujuan untuk mengetahui respon osmotik, regulasi ion dan pertumbuhan elver ikan sidat pada salinitas berbeda. Penelitian dan penulisan dilaksanakan dari Maret-Juli 2018 menggunakan rancangan acak lengkap dengan 3 level salinitas dan 3 kali ulangan. Elver ikan sidat dipelihara pada akuarium dengan ukuran 30 × 20 × $20 \mathrm{~cm}$ yang dilengkapi aerator dan pipa peralon sebagai shelter. Elver ikan sidat dipelihara selama 42 hari dengan pergantian air media dan pemberian pakan setiap 2 hari sekali. Pengukuran panjang dan bobot tubuh dilakukan pada awal dan akhir penelitian. Osmolaritas media dan osmolaritas haemolymph di ukur menggunakan osmometer. Uji pendahuluan dilakukan untuk menentukan salinitas yang digunakan pada uji utama. Hasil yang diperoleh yaitu rata-rata osmolaritas media dan haemolymph pada salinitas $0 \%$, 2\%o dan $4 \%$ berturut-turut bernilai 1,7 \%o mOsm/ $1 \mathrm{H}_{2} \mathrm{O}, 60,28 \mathrm{mOsm} / 1 \mathrm{H}{ }_{2} \mathrm{O}, 116,4$ $\mathrm{mOsm} / 1 \mathrm{H}_{2} \mathrm{O}$ dan 47,56 mOsm/1 $\mathrm{H}_{2} \mathrm{O}, 62,28 \mathrm{mOsm} / 1 \mathrm{H}_{2} \mathrm{O}, 68,1 \mathrm{mOsm} / 1 \mathrm{H}_{2} \mathrm{O}$. Rata-rata panjang tubuh dan penurunan bobot tubuh pada salinitas $0 \%$, 2\%o dan $4 \%$ berturut-turut yaitu 1,05 cm, 2,07 cm, 0,84 cm dan 3,55 g, 0,82 g, 2, $65 \mathrm{~g}$. Konsentrasi ion rata-rata pada salinitas $0 \%$, 2\%o dan $4 \%$ berturut-turut bernilai 0,27 g/l, 3,25 g/l dan 0,21 g/l. Berdasarkan hasil penelitian dapat diketahui bahwa salinitas isoosmotik dan tingkat kerja osmotik terendah pada salinitas $1,97 \%$. Pertumbuhan panjang tertinggi dan penurunan bobot tubuh terendah berada pada salinitas $2 \%$ serta konsentrasi ion tertinggi pada salinitas $2 \%$.
\end{abstract}

Kata kunci : Osmolaritas; TKO; Pertumbuhan; Regulasi ion; Elver Anguilla sp.

\section{ABSTRACT}

Salinity that suits with the fish needs is necessary for the efficient use of energy in the body. This study aims to determine the osmotic response, ion regulation and elver eel fish growth at different salinity. The research was conducted from March to July 2018 and used a complete randomized design with 3 levels of salinity and 3 replications. Elver eel is kept in aquarium with size $30 \times 20 \times 20 \mathrm{~cm}$ which is equipped with aerator and pipe as shelter. Elver eel is maintained for 42 days with water change media and feeding every 2 days. Measurements of length and body weight were performed at the beginning and end of the study. Media osmolarity and haemolymph osmolarity are measured using an osmometer. The experiment preliminary aims to determine salinity that use at experiment prime.The results obtained were the mean of media osmolarity and haemolymph at salinity of $0 \%$, $2 \%$ and $4 \%$ respectively were $1.7 \%$ $\mathrm{mOsm} / \mathrm{l} \mathrm{H} 2 \mathrm{O}, 60.28 \mathrm{mOsm} / \mathrm{l} \mathrm{H} 2 \mathrm{O}, 116.4 \mathrm{mOsm} / \mathrm{l} \mathrm{H}_{2} \mathrm{O}$ and 47,56 mOsm / $\mathrm{l} \mathrm{H} \mathrm{H}_{2} \mathrm{O}, 62.28 \mathrm{mOsm} / \mathrm{l} \mathrm{H}_{2} \mathrm{O}, 68.1 \mathrm{mOsm} / \mathrm{l}$ $\mathrm{H}_{2} \mathrm{O}$. Average of body length and decrease of body weight at salinity of $0 \%$, $2 \%$ and $4 \%$ respectively were $1.05 \mathrm{~cm}$, $2.07 \mathrm{~cm}, 0.84 \mathrm{~cm}$ and $3.55 \mathrm{~g}, 0.82 \mathrm{~g}, 2.65 \mathrm{~g}$. The mean ion concentrations in the salinity of $0 \%$, $2 \%$ and $4 \%$ were $0.27 \mathrm{~g} / \mathrm{l}, 3.25 \mathrm{~g} / \mathrm{l}$ and $0.21 \mathrm{~g} / \mathrm{l}$ respectively. Based on the research results it can be seen that the isoosmotic salinity and the lowest osmotic work rate are at salinity $1.97 \%$. The highest growth length and the lowest body weight decrease is at $2 \%$ salinity and the highest ion concentration is at $2 \%$ salinity.

Keywords: Osmolarity; TKO; Growth; Ion regulation; Elver Anguilla sp.

*) Penulis penanggungjawab

\section{PENDAHULUAN}

Ikan sidat merupakan ikan ekonomis penting di Indonesia dan menjadi salah satu komoditas unggulan di Indonesia. Permintaan ikan sidat dari tahun ketahun semakin meningkat. Menurut Roy (2013), data yang diperoleh Balai Layanan Usaha Produksi Perikanan Budidaya Karawang (BLUPBK) jumlah permintaan terhadap sidat segar beserta olahannya (seperti frozen meat, fillet dan smoke yang dibutuhkan restoran-restoran cepat saji) diseluruh dunia pernah mencapai 300.000 ton per tahun. Untuk memenuhi permintaan ikan sidat yang sangat besar maka dibutuhkan 
produksi ikan sidat yang banyak dengan proses produksi yang cepat. Salah satu cara untuk mempercepat proses produksi adalah dengan menemukan laju pertumbuhan ikan yang paling cepat. Salah satu faktor yang mempengaruhi laju pertumbuhan ikan sidat adalah salinitas. Menurut Yurisma et al, (2013) Salinitas merupakan salah satu faktor pembatas yang berpengaruh pada tingkat konsumsi organisme. Salinitas sebagai salah satu parameter kualitas air berpengaruh secara langsung terhadap metabolisme tubuh ikan, terutama proses osmoregulasi. Dengan memberikan perlakuan salinitas diharapkan mampu meningkatkan efisiensi penggunaan energi dalam proses osmoregulasi pada benih ikan. Salah satu aspek fisiologi ikan yang dipengaruhi oleh salinitas adalah tekanan osmotik dan konsentrasi cairan tubuh serta kebutuhan oksigen. Pengaturan kualitas air yang tepat terutama salinitas sebagai media kultur ikan sidat untuk laju pertumbuhan yang optimal juga belum diketahui. Keadaan ini dapat dilihat dari beragamnya salinitas media yang diaplikasikan untuk kegiatan budidaya ikan sidat. Padahal, kualitas air sangat menentukan tingkat kelulushidupan sidat. Oleh karena itu, perlu diketahui tingkat salinitas yang sesuai dengan kehidupan dan laju pertumbuhan optimal ikan sidat.

Tujuan dari penelitian ini yaitu untuk mengkaji respon osmotik ikan sidat pada salinitas berbeda, mengetahui regulasi ion ikan sidat pada salinitas berbeda, mengetahui pertumbuhan ikan sidat serta kaitannya dengan tingkat kerja osmotik pada salinitas berbeda.

\section{MATERI DAN METODE}

\section{A. Materi Penelitian}

Materi yang digunakan pada penelitian ini terdiri dari alat dan bahan. Adapun alat yang digunakan dalam penelitian ini adalah akuarium, refraktometer, timbangan digital, Automatic Micro Osmometer, microtube, jarum suntik, Aerator, gelas ukur, thermometer, dan pipa peralon. Bahan yang digunakan dalam penelitian ini adalah elver ikan sidat, media air laut dan air tawar.

\section{B. Metode Penelitian}

Metode yang digunakan dalam penelitian ini adalah metode eksperimental laboratorium. Uji pendahuluan dilakukan sebelum melakukan uji utama. Uji pendahuluan dilakukan untuk menentukan salinitas yang akan digunakan pada uji utama. Perlakuan yang dilakukan pertama yaitu melakukan aklimasi elver ikan sidat selama 24 jam pada media air tawar. Selanjutnya perlakuan aklimatisasi dilakukan dengan memasukkan elver ikan sidat ke dalam tiga akuarium dengan salinitas $0 \%$, $5 \%$, dan $10 \%$. Menurut Indrawati et al., (2016), selama stadia pasca larva hingga menjelang matang kelamin sidat hidup di perairan tawar dengan media bersalinitas rendah oligohaline $(5-0,5 \%$ oo $)$. Hasil uji pendahuluan didapatkan bahwa level salinitas terbawah $0 \%$ o dan level teratas $5 \%$. Oleh karena itu, salinitas yang digunakan pada uji utama yaitu $0 \%$, $2 \%$, dan $4 \%$.

Selanjutnya masuk ke tahap uji utama dengan memasukan elver ikan kedalam akuarium berukuran $30 \mathrm{X} 20 \mathrm{X}$ $20 \mathrm{~cm}$ yang masing-masing sudah diatur salinitasnya yaitu $0 \%$, $2 \%$, dan $4 \%$. Volume air pada setiap akuarium yaitu 6 liter. Masing-masing akuarium diisi 5 ekor elver ikan sidat. Setiap akuarium dilengkapi dengan aerator dan pipa peralon sebagai shelter. Kultivasi dilakukan selama 42 hari untuk mendapatkan data pertumbuhan yang memadai. Pengukuran panjang dan bobot tubuh elver ikan sidat dilakukan pada awal dan akhir kultivasi. Pengukuran osmolaritas media dan haemolymph dilakukan setelah elver ikan sidat mati pada saat masa kultivasi dan diakhir masa kultivasi. Pengukuran konsentrasi ion dilakukan pada akhir masa kultivasi.

\section{Parameter yang Diamati}

\section{a. Tingkat Kerja Osmotik}

Perhitungan tingkat kerja osmotik menggunakan rumus berikut (Anggoro and Nakamura, 1996) :

$$
T K O=[\text { osmolaritas darah }- \text { osmolaritas media }]
$$

Keterangan :

TKO : tingkat kerja osmotik, mOSM/l $\mathrm{H}_{2} \mathrm{O}$

$\mathrm{P}$ osmo darah : tekanan osmotik darah, mOSM/l $\mathrm{H}_{2} \mathrm{O}$

P osmo media : tekanan osmotik media pemeliharaan, mOSM/l $\mathrm{H}_{2} \mathrm{O}$

\section{b. Pertumbahan Bobot}

Menurut Day dan Fleming (1992), laju pertambahan bobot dihitung dengan rumus sebagai berikut :

$$
W i=W t-W o
$$

Keterangan :

$W i=$ Pertumbuhan mutlak bobot tubuh rata-rata $(\mathrm{g})$

$W t=$ Bobot rata-rata ikan pada waktu ke-t pemeliharaan $(\mathrm{g})$

$W 0=$ Bobot rata-rata ikan pada awal pemeliharaan $(\mathrm{g})$

\section{c. Pertumbahan Panjang}

Laju pertumbuhan panjang menurut (Effendi, 1979), diukur sebagai berikut :

$$
P m=P t-P 0
$$


Keterangan :

$\mathrm{P}_{\mathrm{m}}=$ panjang mutlak ikan $(\mathrm{cm})$

$\mathrm{P}_{0}=$ panjang ikan pada hari ke-0 $(\mathrm{cm})$

$\mathrm{P}_{\mathrm{t}}=$ panjang ikan pada hari ke- $\mathrm{t}(\mathrm{cm})$

\section{d. Kelangsungan Hidup}

Persentase kelangsungan hidup dihitung dengan rumus dari Wirabakti (2006) sebagai berikut :

$$
\begin{aligned}
K H & =N t \times 100 \% \\
N o &
\end{aligned}
$$

Keterangan :

$\mathrm{KH}=$ Kelangsungan Hidup (\%)

$\mathrm{Nt} \quad=$ Jumlah ikan yang hidup pada akhir pemeliharaan (ekor)

No = Jumlah ikan pada awal pemeliharaan (ekor)

\section{HASIL DAN PEMBAHASAN}

\section{HASIL}

Rata-rata osmolaritas media dan osmolaritas haemolymph elver ikan sidat (Anguilla sp.) yang dipelihara pada salinitas berbeda ditunjukkan pada Gambar 1.

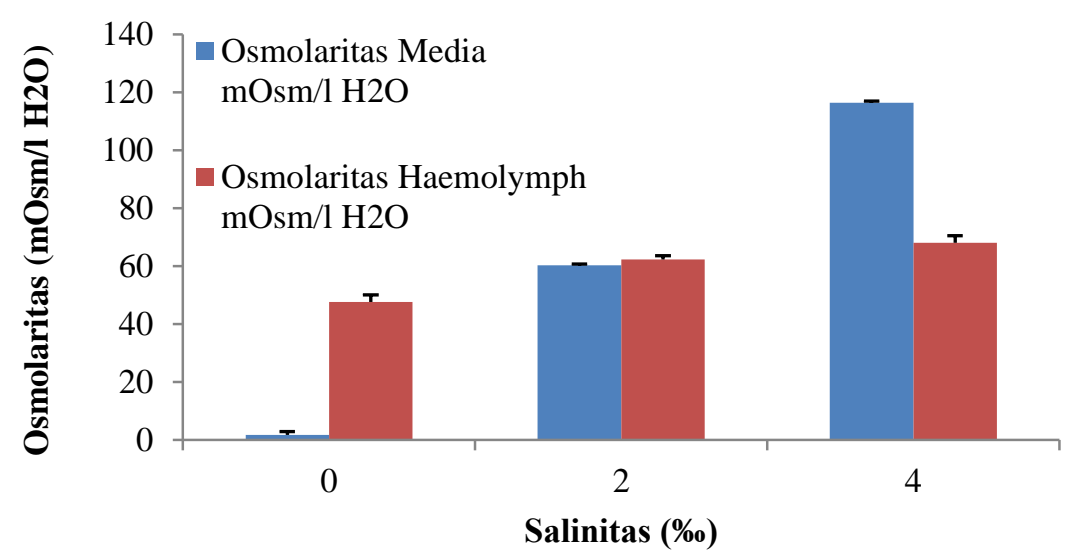

Gambar 1. Pengaruh Salinitas terhadap Osmolaritas Media dan Osmolaritas Haemolymph Elver Sidat Anguilla sp.

Diperoleh rata-rata osmolaritas media pada salinitas $0 \%$, 2\% dan $4 \%$ berturut-turut bernilai $1,7 \pm 1,20 \%$ $\mathrm{mOsm} / 1 \mathrm{H}_{2} \mathrm{O}, 60,28 \pm 0,47 \mathrm{mOsm} / 1 \mathrm{H}_{2} \mathrm{O}$ dan $116,4 \pm 0,55 \mathrm{mOsm} / 1 \mathrm{H}_{2} \mathrm{O}$. Rata-rata osmolaritas haemolymph pada salinitas $0 \%$, $2 \%$ dan $4 \%$ berturut-turut bernilai $47,56 \pm 2,46 \mathrm{mOsm} / 1 \mathrm{H}_{2} \mathrm{O}, 62,28 \pm 1,38 \mathrm{mOsm} / 1 \mathrm{H}_{2} \mathrm{O}$ dan $68,1 \pm 2,46 \mathrm{mOsm} / 1$ $\mathrm{H}_{2} \mathrm{O}$. Hubungan osmolaritas haemolymph dan osmolaritas media elver ikan sidat ditunjukkan pada Gambar 2

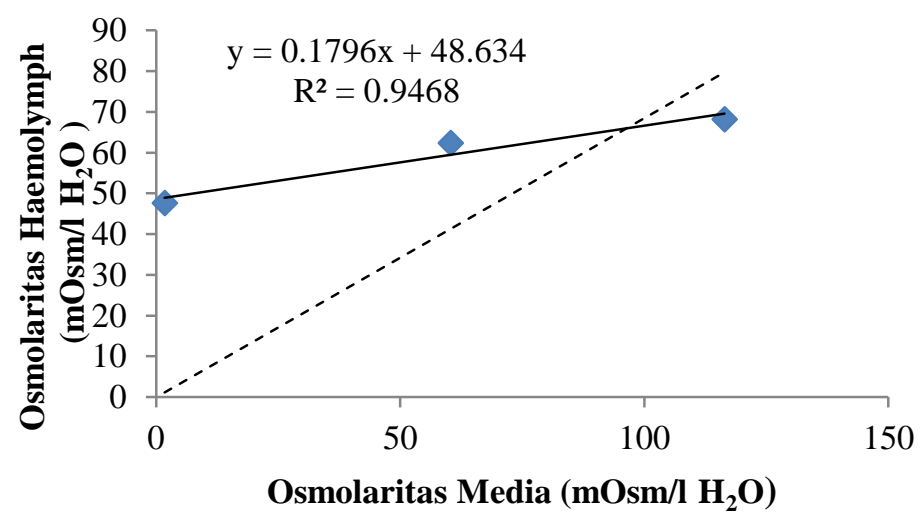

Gambar 2. Grafik Hubungan Osmolaritas Haemolymph dan Osmolaritas Media Ikan Sidat Anguilla sp. pada Salinitas Berbeda.

Persamaan hubungan osmolaritas haemolymph dan osmolaritas media memperlihatkan korelasi positif yang sangat kuat $\mathrm{R}^{2}=0,9468$. Bedasarkan persamaan $\mathrm{y}=0,1796 \mathrm{x}+48,634$ diketahui bahwa elver ikan sidat Anguilla $\mathrm{sp}$. berada pada kondisi isoosmotik pada osmolaritas 59, $28 \mathrm{mOsm} / 1 \mathrm{H}_{2} \mathrm{O}$ atau pada salinitas 1,97 \%o. Pengaruh salinitas terhadap tingkat kerja osmotik (TKO) elver ikan sidat Anguilla sp. disajikan pada Gambar 3 dan 4. 


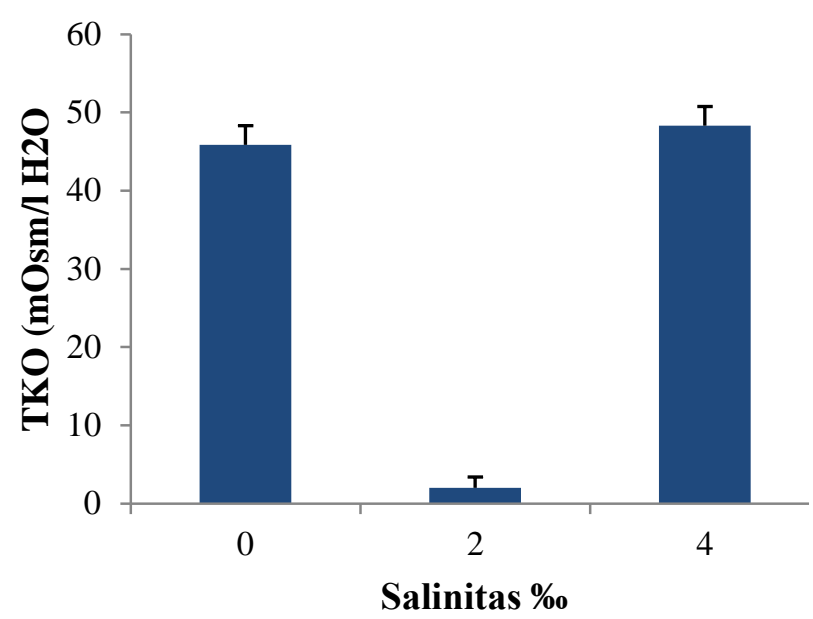

Gambar 3. Nilai Tingkat Kerja Osmotik (TKO) Elver Ikan Sidat Anguilla sp. pada Salinitas Media Berbeda.

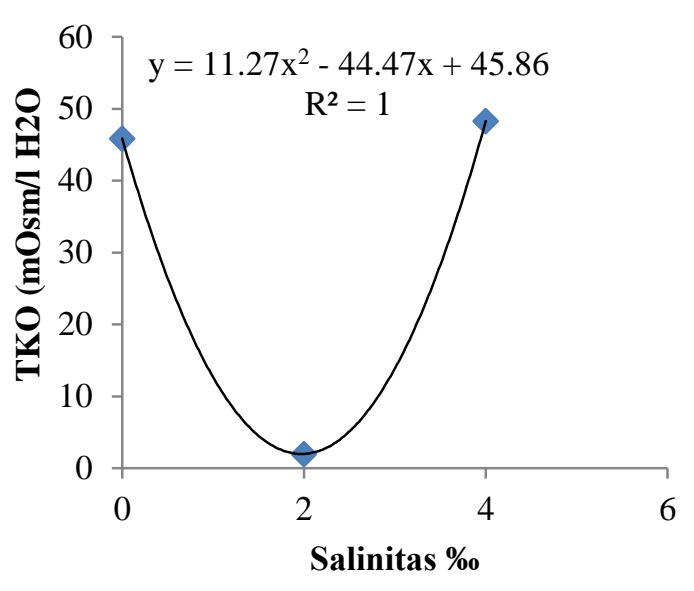

Gambar 4. Kurva Respon Tingkat Kerja Osmotic (TKO) Elver Ikan Sidat Anguilla sp. pada Media Salinitas Berbeda

Nilai tingkat kerja osmotik (TKO) rata-rata pada salinitas $0 \%$, 2\%o dan $4 \%$ berturut-turut yaitu 5,86 $\pm 2,46$ $\mathrm{mOsm} / 1 \mathrm{H}_{2} \mathrm{O}, 2 \mathrm{mOsm} / 1 \mathrm{H}_{2} \mathrm{O} \pm 1,38$ dan 48,3 $\pm 2,46 \mathrm{mOsm} / 1 \mathrm{H}_{2} \mathrm{O}$. Berdasarkan kurva respon tingkat kerja osmotic (TKO) diatas dapat diketahui bahwa kurva membentuk pola kuadratik dengan persamaan $\mathrm{y}=11,27 \mathrm{x}^{2}-44,47 \mathrm{x}+45,86$. Tingkat kerja osmotik (TKO) terendah berdasarkan persamaan kurva tersebut yaitu berada pada nilai salinitas 1,97 \%o. Pengaruh faktor salinitas terhadap nilai tingkat kerja osmotik pada penelitian ini diperoleh sebesar $100 \%$. Hasil yang diperoleh berdasarkan pengukuran dan pengamatan panjang tubuh dan bobot tubuh elver ikan sidat yang di pelihara pada salinitas $0 \%$, 2 \%o dan $4 \%$ selama 42 hari masa pemeliharaan disajikan pada Tabel 1.

Tabel 1. Pertumbuhan Mutlak Bobot Tubuh (W) dan Panjang Tubuh (L) Elver Ikan Sidat Anguilla sp. pada Media Salinitas Berbeda

\begin{tabular}{lccc}
\hline \multicolumn{1}{c}{ Parameter } & \multicolumn{1}{c}{ Salinitas (\%o) } \\
\hline Bobot & $\mathbf{0}$ & $\mathbf{2}$ & $\mathbf{4}$ \\
\hline Wawal $(\mathrm{g})$ & 27,69 & 33,52 & 35,93 \\
Wakhir(g) & 24,14 & 32,71 & 33,28 \\
Wi (g) & $-3,55$ & $-0,82$ & $-2,65$ \\
\hline Panjang & & & 28,17 \\
\hline Lawal $(\mathrm{cm})$ & 26,11 & 26,71 & 29,01 \\
Lakhir(cm) & 27,16 & 28,78 & 0,84 \\
Li(cm) & 1,05 & 2,07 & \\
\hline
\end{tabular}

Respon pertumbuhan bobot dan panjang tubuh elver ikan sidat anguilla sp. pada salinitas $0 \%$, $2 \%$ dan $4 \%$ ditunjukkan pada Gambar 5 dan 6.

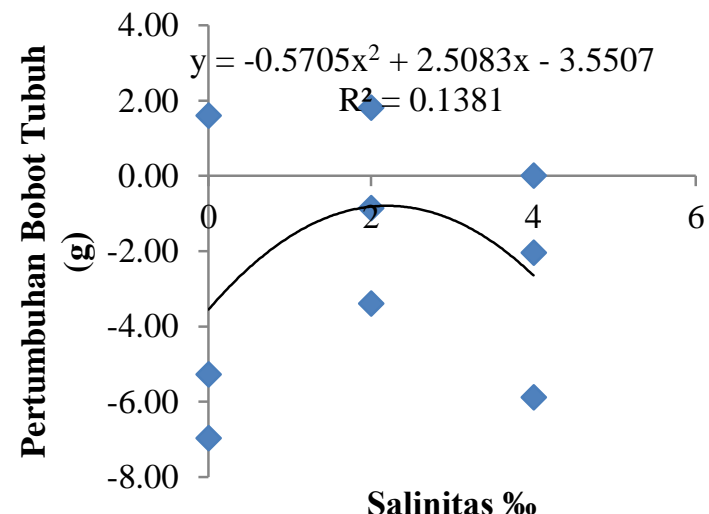

Salinitas \%o

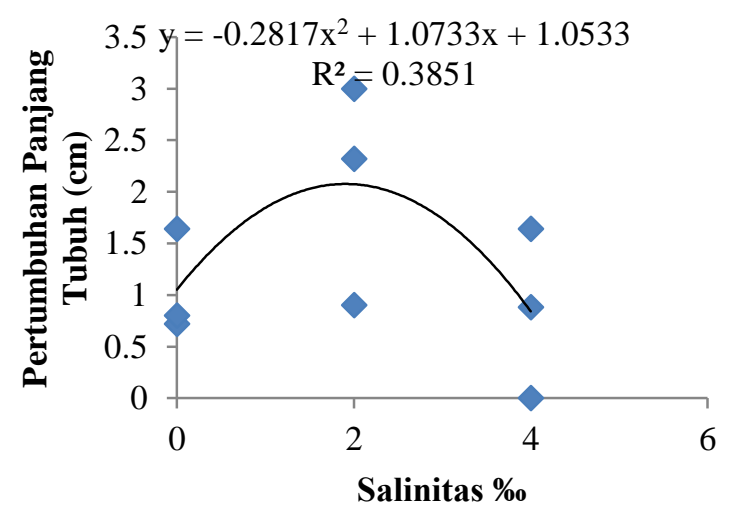

Gambar 5. Kurva Respon Pertumbuhan Bobot Tubuh Gambar 6. Kurva Respon Pertumbuhan Panjang Tubuh Elver Ikan Sidat Anguilla sp. pada Salinitas $0 \%$, $2 \%$ dan $4 \%$. Elver Ikan Sidat Anguilla sp. pada Salinitas Berbeda. 
Berdasarkan Kurva respon pertumbuhan bobot tubuh elver ikan sidat Anguilla sp. pada salinitas $0 \%$ o, 2 \%о dan $4 \%$ diperoleh bahwa bahwa kurva membentuk pola kuadratik dengan persamaan $y=-0,5705 x^{2}+2,5083 x-3,5507$. Berdasarkan persamaan tersebut dapat diketahui pertumbuhan bobot optimal elver ikan sidat yaitu pada salinitas 2,198 $\%$.

Berdasarkan Kurva respon pertumbuhan panjang tubuh elver ikan sidat Anguilla sp. pada salinitas $0 \%$, $2 \%$ dan $4 \%$ diperoleh bahwa bahwa kurva membentuk pola kuadratik dengan persamaan $\mathrm{y}=-0,2817 \mathrm{x}^{2}+1,0733 \mathrm{x}+$ 1,0533. Berdasarkan persamaan tersebut dapat diketahui pertumbuhan panjang optimal elver ikan sidat yaitu pada salinitas 1,9 \%o. Tingkat kelangsungan hidup elver ikan sidat ( Anguilla sp.) selama masa proses pemeliharaan ditunjukkan pada Gambar 7

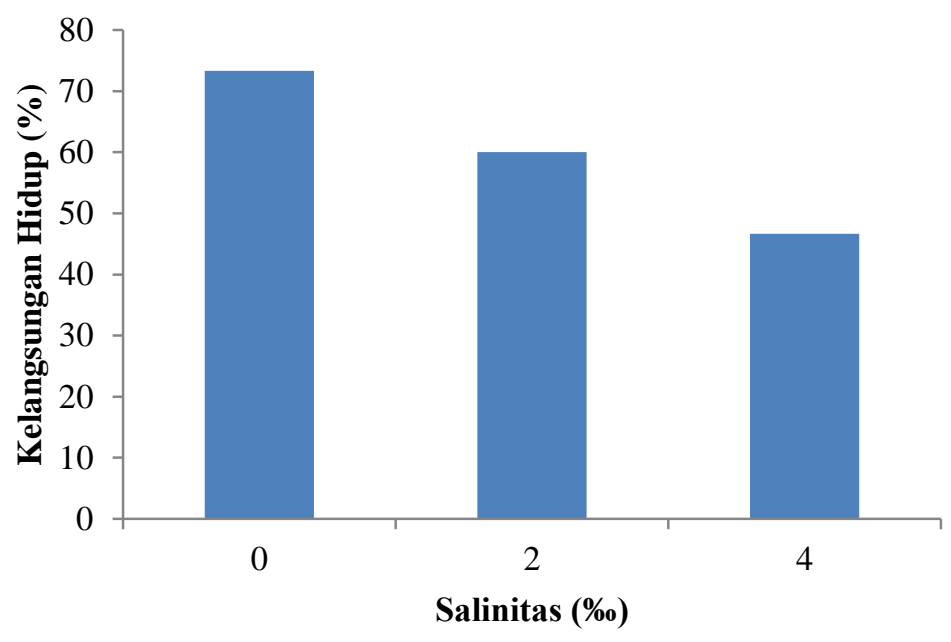

Gambar 7. Tingkat Kelangsungan Hidup Elver Ikan Sidat Anguilla sp. pada Salinitas 0 \%, 2 \%o dan 4 \%o Selama Masa Pemeliharaan.

Tingkat kelangsungan hidup elver ikan sidat pada salinitas $0 \%$, $2 \%$ dan $4 \%$ berturut-turut yaitu 73,33 \%, 60 $\%$ dan 46,67 \%. Kelangsungan hidup elver ikan sidat mengalami penurunan seiring dengan meningkatnya salinitas media pemeliharaan. Kelangsungan hidup elver ikan sidat tertinggi terjadi pada salinitas $0 \%$ dan terendah terjadi pada salinitas $4 \%$. Konsentrasi ion $\mathrm{K}^{+}, \mathrm{Na}^{+}, \mathrm{Ca}^{2+}, \mathrm{Cl}^{-}$dan $\mathrm{Mg}^{2+}$ pada media dan haemplymph ditunjukkan pada tabel 2 dan Tabel 3

Tabel 2. Konsentrasi Ion Media

Tabel 3. Konsentrasi Ion Haemolymph

\begin{tabular}{ccccc}
\hline \multirow{2}{*}{$\begin{array}{c}\text { Elektrolit } \\
(\mathbf{g} / \mathbf{l})\end{array}$} & \multicolumn{3}{c}{ Ion Media } & Jumlah \\
\cline { 2 - 4 } & $\mathbf{0} \%$ & $\mathbf{2 \% o}$ & $\mathbf{4} \% \mathbf{0}$ & \\
\hline $\mathbf{N a}^{+}$ & 0,00 & 1,13 & 1,87 & 2,99 \\
$\mathbf{C l}^{-}$ & 0,00 & 1,29 & 1,97 & 3,26 \\
$\mathbf{C a}^{2+}$ & 0,01 & 0,17 & 0,37 & 0,55 \\
$\mathbf{M g}^{2+}$ & 0,01 & 0,17 & 0,40 & 0,57 \\
$\mathbf{K}^{+}$ & 0,01 & 0,05 & 0,12 & 0,19 \\
\hline$\sum$ & 0,03 & 2,81 & 4,73 & 7,57 \\
\hline
\end{tabular}

\begin{tabular}{|c|c|c|c|c|}
\hline \multirow{2}{*}{ Elektrolit (g/l) } & \multicolumn{3}{|c|}{ Ion Haemolymph } & \multirow{2}{*}{ Jumlah } \\
\hline & $0 \%$ & $2 \%$ & $4 \%$ & \\
\hline $\mathrm{Na}^{+}$ & 0,12 & 1,80 & 1,80 & 3,72 \\
\hline $\mathrm{Cl}^{-}$ & 0,13 & 1,93 & 1,94 & 4,01 \\
\hline $\mathrm{Ca}^{2+}$ & 0,01 & 0,98 & 0,40 & 1,38 \\
\hline $\mathrm{Mg}^{2+}$ & 0,01 & 0,98 & 0,38 & 1,37 \\
\hline $\mathbf{K}^{+}$ & 0,00 & 0,37 & 0,20 & 0,57 \\
\hline$\sum$ & 0,28 & 6,06 & 4,72 & 11,05 \\
\hline
\end{tabular}

Konsentrasi ion media tertinggi terdapat pada ion klor yaitu 3, $26 \mathrm{~g} / \mathrm{l}$ dan ion terendah yaitu kalium dengan nilai $0,19 \mathrm{~g} / \mathrm{l}$. Konsentrasi ion haemolymp tertinggi juga sama dengan ion media yaitu ion klor dengan nilai 4, $01 \mathrm{~g} / \mathrm{l}$ dan kalium dengan nilai $0,57 \mathrm{~g} / \mathrm{l}$ menjadi ion dengan nilai terendah. Konsentrasi ion $\mathrm{K}^{+}, \mathrm{Na}^{+}, \mathrm{Ca}^{2+}, \mathrm{Cl}^{-} \mathrm{dan}^{\mathrm{Mg}}{ }^{2+}$ media dan haemolymph elver ikan sidat (Anguilla sp.) pada salinitas berbeda ditunjukkan pada Tabel 4.

Konsentrasi ion pada salinitas $0 \%$, $2 \%$ dan $4 \%$ berturut-turut yaitu 0, $27 \mathrm{~g} / \mathrm{l}, 3,25 \mathrm{~g} / \mathrm{l}$ dan 0,21 g/l. Berdasarkan diagram diatas dapat diketahui bahwa salinitas $2 \%$ memiliki konsentrasi ion tertinggi. Sedangkan, salinitas $0 \%$ dan $4 \%$ memiliki konsentrasi ion yang hamper sama. Konsentrasi ion pada salinitas $0 \%$ lebih tinggi disbanding konsentrasi ion pada salinitas 4 \%. Hubungan kelangsungan hidup, pertumbuhan, tingkat kerja osmotik dan konsentrasi ion ditunjukkan pada Gambar 8. 
Tabel 4. Konsentrasi Ion $\mathrm{K}^{+}, \mathrm{Na}^{+}, \mathrm{Ca}^{2+}, \mathrm{Cl}^{-}$dan $\mathrm{Mg}^{2+}$ Media dan Haemolymph Elver Ikan Sidat (Anguilla sp.) pada Salinitas Berbeda

\begin{tabular}{cccc}
\hline \multirow{2}{*}{ Elektrolit (g/l) } & \multicolumn{3}{c}{$\boldsymbol{\Delta}$ ion } \\
\cline { 2 - 4 } & $\mathbf{0} \% \mathbf{0}$ & $\mathbf{2} \% \mathbf{~}$ \\
\hline $\mathbf{N a}^{+}$ & 0,123 & 0,67 & 0,07 \\
$\mathbf{C l}$ & 0,133 & 0,64 & 0,03 \\
$\mathbf{C a}^{2+}$ & 0 & 0,81 & 0,02 \\
$\mathbf{M g}^{2+}$ & 0 & 0,81 & 0,01 \\
$\mathbf{K}^{+}$ & 0,01 & 0,32 & 0,08 \\
\hline$\Sigma$ & 0,27 & 3,25 & 0,21 \\
\hline
\end{tabular}

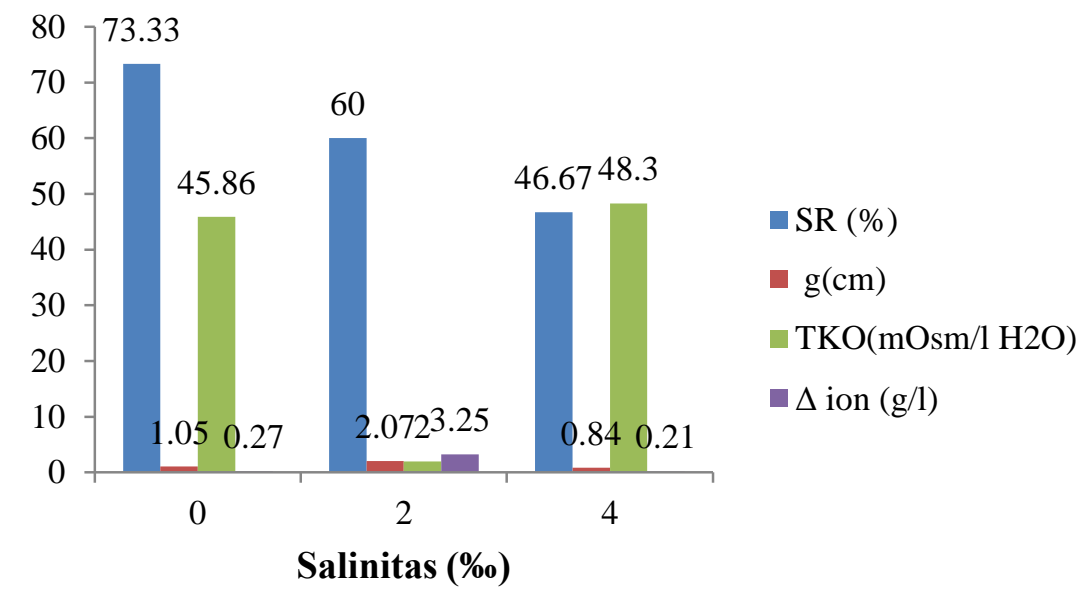

Gambar 8. Hubungan kelangsungan hidup, pertumbuhan, tingkat kerja osmotik dan konsentrasi ion.

Elver ikan sidat (Anguilla sp.) pada salinitas $0 \%$ memiliki tingkat kelangsungan hidup 73,33\%, pertumbuhan panjang tubuh $1,05 \mathrm{~cm}$, tingkat kerja osmotik (TKO) $45,86 \mathrm{mOsm} / 1 \mathrm{H}_{2} \mathrm{O}$ dan konsentrasi ion $0,27 \mathrm{~g} / \mathrm{l}$. Elver ikan sidat (Anguilla sp.) pada salinitas $2 \%$ memiliki tingkat kelangsungan hidup $60 \%$, pertumbuhan panjang tubuh 2,07 cm, tingkat kerja osmotik (TKO) $2 \mathrm{mOsm} / 1 \mathrm{H}_{2} \mathrm{O}$ dan konsentrasi ion 3,25 g/l. Elver ikan sidat (Anguilla sp.) pada salinitas 4 $\%$ memiliki tingkat kelangsungan hidup $46,67 \%$, pertumbuhan panjang tubuh $0,84 \mathrm{~cm}$, tingkat kerja osmotik (TKO) $48,3 \mathrm{mOsm} / 1 \mathrm{H}_{2} \mathrm{O}$ dan konsentrasi ion $0,21 \mathrm{~g} / \mathrm{l}$.

\section{PEMBAHASAN \\ Respon Osmotik}

Salinitas lingkungan dapat merubah pengaruh osmoregulasi, kontrol hormonal, energi metabolisme dan pertumbuhan. Salinitas lingkungan secara langsung mempengaruhi fisiologi organisme akuatik dan oleh karena itu, salinitas merupakan faktor ekologi yang sangat penting (Urbina dan Glover, 2015). Salinitas merupakan faktor yang mempengaruhi tekanan osmosis, dimana semakin tinggi salinitas maka akan semakin tinggi pula tekanan osmosisnya (Maulana et al., 2013). Pertumbuhan ikan akan lebih cepat pada kondisi isoosmotik. Hal ini sesuai dengan hasil penelitian dimana pertumbuhan panjang lebih cepat terjadi pada salinitas $2 \%$. Salinitas $2 \%$ merupakan salinitas yang paling mendekati kondisi isoosmotik yang dibutuhkan oleh elver ikan sidat. Kondisi isoosmotik yang paling tepat yaitu berada pada salinitas 1,97 \%. Salinitas 1,97 \%o memiliki osmolaritas 59,28 mOsm/1 H2O. Salinitas $2 \%$ sendiri memiliki osmolaritas media $60,28 \mathrm{mOsm} / 1 \mathrm{H} 2 \mathrm{O}$ dan osmolaritas haemolymph $62,28 \mathrm{mOsm} / \mathrm{l} \mathrm{H} 2 \mathrm{O}$, sehingga memiliki nilai tingkat kerja osmotik (TKO) 2 mOsm/l H2O. Menurut Saridu et al., (2017), bahwa lambatnya pertumbuhan pada media kultivasi dengan gradien osmotik yang besar disebabkan karena pembelanjaan energi lebih diutamakan untuk mencapai kondisi homeostatis yaitu kondisi dimana terjadi keseimbangan osmotik antara media kultivasi dan cairan sel organisme.

\section{Pertumbuhan}

Pertumbuhan panjang tubuh elver ikan sidat pada salinitas $2 \%$ yaitu rata-rata mencapai $2,07 \mathrm{~cm}$. Diikuti oleh ikan sidat yang dipelihara pada salinitas $0 \%$ yaitu $1,05 \mathrm{~cm}$. Pertumbuhan panjang tubuh terendah terjadi pada ikan sidat yang dipelihara pada salinitas $4 \%$ dengan panjang $0,84 \mathrm{~cm}$. Salinitas $2 \%$ juga merupakan salinitas isoosmotik, 
sehingga tingkat kerja osmotik (TKO) pada salinitas ini cukup kecil dibandingkan pada salinitas lainnya. Tingkat kerja osmotik (TKO) rendah menyebabkan energi yang digunakan untuk kegiatan metabolisme juga menjadi rendah, sehingga energi dapat difungsikan untuk kegiatan lain misalnya pertumbuhan. Menurut Anggoro et al., (2013), Kondisi isoosmotik kandungan ion-ion dalam darah ikan setara dengan media hidupnya, energi untuk aktivitas osmoregulasi kecil sebagai akibat adanya keseimbangan cairan tubuh dengan lingkungan luar sehingga sisa porsi energi yang lebih besar dapat digunakan untuk pertumbuhan. Faktor lain yang mempengaruhi pertumbuhan panjang tubuh ikan yaitu temperatur. Temperatur mempengaruhi kecepatan metabolisme tubuh ikan. Apabila kegiatan metabolisme berlangsung terlalu cepat, maka energi yang digunakan untuk kegiatan metabolisme ini pun besar. Besarnya energi yang digunakan untuk kegiatan metabolisme menyebabkan ketersediaan energi untuk kegiatan pertumbuhan menjadi kecil, sehingga pertumbuhan akan berlangsung lambat. Oleh karena itu, dibutuhkan energi yang sesuai dengan yang dibutuhkan untuk kehidupan elver ikan sidat. Menurut Matthias et al., (2018), pertumbuhan panjang dipengaruhi oleh temperature, dengan pertumbuhan tercepat yaitu pada termperatur optimal dan pertumbuhan lebih lambat ketika temperatur terlalu dingin (48\% lebih lambat) atau terlalu panas (82\% lebih lambat), dan secara negatif berkaitan dengan densitas, dengan $25 \%$ pertumbuhan lebih lambat pada densitas tinggi

\section{Kelangsungan Hidup}

Tingkat kelangsungan hidup elver ikan sidat semakin menurun dengan adanya peningkatan nilai salinitas. Tingkat kelangsungan hidup elver ikan sidat pada salinitas $0 \%$ merupakan tingkat kelangsungan hidup tertinggi dibanding dengan tingkat kelangsungan hidup pada salinitas $2 \%$ dan $4 \%$. Tingkat kelangsungan hidup pada salinitas ini mencapai 73,33\%. Tingkat kelangsungan hidup pada salinitas $2 \%$ mencapai $60 \%$. Tingkat kelangsungan hidup pada salinitas ini merupakan tingkat kelangsungan hidup tertinggi kedua setelah tingkat kelangsungan hidup pada salinitas $0 \%$. Tingkat kelangsungan hidup terendah yaitu elver ikan sidat pada salinitas 4 \%o dengan nilai tingkat kelangsungan hidup 46,67 \%. Menurut Hidayat et al., (2013), kelangsungan hidup benih ikan selama 30 hari pemeliharaan pada semua perlakuan berkisar antara $50 \%-86,67 \%$. Berdasarkan hasil pengamatan benih ikan selama pemeliharaan, kematian benih ikan diduga akibat infeksi bakteri dan jamur. Kelainan klinis seperti timbul bentuk kapas putih pada tubuh benih ikan, mata menonjol, adanya bercak merah pada salah satu sirip dada, seluruh tubuh melepuh, dan luka-luka. Adanya penyakit pada benih ikan, terjadi pada saat dua minggu pemeliharan benih ikan.

Faktor yang mempengaruhi tingkat kelangsungan hidup elver ikan sidat tidat hanya salinitas. Akan tetapi ada faktor-faktor lain yang mempengaruhinya. Faktor-faktor lain yang mempengaruhi tingkat kelangsungan hidup elver ikan sidat anatara lain tingkat stress, penyakit, pakan, penambahan probiotik dan lain-lain. Berdasarkan analisis keragaman, penambahan probiotik dalam pakan berpengaruh nyata terhadap kelangsungan hidup benih ikan. Kelangsungan hidup benih ikan cenderung meningkat dengan semakin tingginya penambahan konsentrasi probiotik (Agustin et al., 2014).

\section{Konsentrasi Ion}

Konsentrasi ion media tertinggi terdapat pada ion klor yaitu 3,26 g/l dan ion terendah yaitu kalium dengan nilai $0,19 \mathrm{~g} / \mathrm{l}$. Konsentrasi ion haemolymph tertinggi juga sama dengan ion media yaitu ion klor dengan nilai 4,01 g/l dan kalium dengan nilai $0,57 \mathrm{~g} / \mathrm{l}$ menjadi ion dengan nilai terendah. Natrium merupakan konsentrasi ion tertinggi kedua baik pada media maupun haemolymph. Konsentrasi ion natrium pada media yaitu 2,99 g/l dan 3,72 g/l pada haemolymph. Sebagai osmoregulator yang efisien, teleostei mempertahankan hidromineralnya homoeostasis dengan menciptakan gradien ionik dan osmotik yang optimal antara cairan tubuh dan lingkungan luar, memanfaatkan fungsi terpadu insang, ginjal dan usus. Berlawanan dengan ikan air laut yang mengeluarkan ion berlebih untuk melawan kelebihan ion, ikan air tawar menyerap ion untuk menghindari hilangnya ion. Ikan mengadopsi strategi osmotik ini dengan mengatur dan mengintegrasikan kompetensi osmotik organ tubuh mereka dengan bantuan hormon (Peter et al., 2011).

\section{Keterkaitan Kelangsungan Hidup, Pertumbuhan, Tingkat Kerja Osmoti dan Elektrolit}

Tingkat kerja osmotik terendah, konsentrasi ion tertinggi, panjang tubuh tertinggi berada pada salinitas $2 \%$. Salinitas $2 \%$ merupakan salinitas yang paling mendekati kondisi isoosmotik, dimana kondisi isoosmotik elver ikan sidat sendiri yaitu 1,97 \%o. Kondisi isoosmotik merupakan kondisi ideal untuk hidup elver ikan sidat. Tingkat kerja osmotik yang rendah menyebabkan energi dapat dialih fungsikan untuk kegiatan lain seperti pertumbuhan. Oleh karena itu, pada salinitas ini elver ikan sidat mengalami pertumbuhan panjang terpanjang. Tingkat kelulus hidupan salinitas ini juga mencapai $60 \%$. Menurut Anggoro et al., (2013), pada kondisi isoosmotik kandungan ion-ion dalam darah ikan setara dengan media hidupnya, energi untuk aktivitas osmoregulasi kecil sebagai akibat adanya keseimbangan cairan tubuh dengan lingkungan luar sehingga sisa porsi energi yang lebih besar dapat digunakan untuk pertumbuhan.

Tingkat kerja osmotik tertinggi berada pada salinitas 4 \%. Tingkat kelulushidupan terendah, konsentrasi ion terendah dan pertumbuhan panjang tubuk terpendek juga terdapat pada salinitas ini. Demikian dapat diketahui bahwa pada kondisi tingkat kerja osmotik yang tinggi menyebabkan energi lebih banyak digunakan untuk menyeimbangkan kondisi tubuh dan lingkungan atau untuk mencapai kondisi isoosmotik. Salinitas 4 \%o sendiri merupakan salinitas hiperosmotik bagi elver ikan sidat. Energi yang banyak digunakan untuk mencapai keadaan homeostasis menyebabkan 
energy yang dapat digunakan untuk pertumbuhan menjadi sedikit atau elver ikan sidat dapat mengalami pertumbuhan yang lambat. Hal ini juga berdampak pada tingkat kelulus hidupan elver ikan sidat yang kecil yaitu hanya mencapai 46,67 \%. Hasil laju pertumbuhan relatif yang didapatkan selama penelitian yang dikultivasi selama 60 hari menunjukkan bahwa rata-rata laju pertumbuhan relatif di stasiun pertama sebesar 220,69\%, stasiun kedua sebesar 190,16\% dan stasiun ketiga sebesar 133,33\%. Nilai laju pertumbuhan relatif tertinggi berada pada stasiun pertama, hal ini diduga berkaitan dengan tingkat kerja osmotik yang rendah, sehingga energi yang digunakan untuk proses osmoregulasi kecil dan sisa energi tersebut dapat digunakan untuk pertumbuhan dengan tinggi, sedangkan nilai laju pertumbuhan relative terendah berada pada stasiun ketiga, diduga berkaitan dengan tingkat kerja osmotik yang tinggi, hal ini mengakibatkan keperluan energi untuk proses osmoregulasi yang besar menyebabkan energi untuk pertumbuhan yang rendah (Temmy et al., 2017).

\section{KESIMPULAN}

Berdasarkan hasil penelitian, maka dapat ditarik kesimpulan bahwa rentang isoosmotik elver ikan sidat berada pada media dengan salinitas 1-2 \%o. Konsentrasi ion pada millien interior (darah sidat) tertinggi berada pada salinitas 2 \%o dan konsentrasi ion terendah berada pada salinitas $4 \%$. Elver ikan sidat (Anguilla sp.) memiliki pertumbuhan panjang lebih tinggi pada salinitas $2 \%$. Pertumbuhan bobot optimal juga terjadi pada salinitas $2 \%$. Salinitas $2 \%$ mendekati salinitas isoosmotik yaitu $1,97 \%$ dan memiliki tingkat kerja osmotik (TKO) terendah. Tingkat kerja osmotik (TKO) yang rendah menjadikan energi yang dipakai untuk kegiatan osmoregulasi juga rendah, sehingga porsi energi dapat digunakan lebih banyak untuk pertumbuhan.

\section{UCAPAN TERIMA KASIH}

Penulis mengucapkan terima kasih kepada Dr. Ir. Abdul Ghofar, M. Sc dan Ir. Siti Rudiyanti, M. Si atas masukan dan saran dalam pembuatan jurnal ini.

\section{DAFTAR PUSTAKA}

Agustin, R., A. D. Sasanti dan Yulisman. 2014. Konversi pakan, laju pertumbuhan, kelangsungan hidup dan populasi bakteri benih ikan gabus (Channa striata) yang diberi pakan dengan penambahan probiotik. Jurnal Akuakultur Rawa Indonesia 2(1) :55- 66.

Anggoro, S and K. Nakamura. 1996. Osmotic respons and biogenertics of kuruma prawn (Penaeus japonicus) in various molting stages and salinities. J. Kagoshima Fish Sci., 9(3): 15-30.

Anggoro,S. Rudiyanti, dan I. Y. Rahmawati. 2013. Domestikasi ikan kerapu macan (Epinephelus fuscoguttatus) melalui optimalisasi media dan pakan. Journal of Management of Aquatic Resources 2(3):119-127.

Day, R.W. and A.E. Fleming. 1992. The Determinants and Measurement of Abalone Growth. In: S.A. Shepherd, M. J. Tegner and S.A.d.P Guzman. Abalone of The World: Biology, Fisheries and Culture. First International Symposium on Abalone, La Paz, Mexico. Oxford: Blackwell Scientific Publications Ltd. 141-165 pp.

Effendi, M. I. 1979. Metode biologi perikanan. Bogor : Yayasan Dewi Sri. P :112.

Hidayat, D., A. D. Sasanti dan Yulisman. 2013. Kelangsungan hidup, pertumbuhan dan efisiensi pakan ikan gabus (Channa striata) yang diberi pakan berbahan baku tepung keong mas (Pomacea sp.). Jurnal Akuakultur Rawa Indonesia 1(2): 161-172.

Indrawati, A., S. Anggoro dan Suradi W.S. 2016. Kajian ruaya larva sidat (glass eel) sebagai basis data pengelolaan sumberdaya sidat di sungai jali, kabupaten purworejo. Prosiding Seminar Nasional Tahunan Ke-V HasilHasil Penelitian Perikanan dan Kelautan, Semarang, 669-679.

Matthias, B. G., R. N. M. Ahrens., M. S. Allen., T. Tuten., Z. A. Siders and K. L. Wilson. 2018. Understanding the effects of density and environmental variability on the process of fish growth. Fisheries Research 198: 209219.

Maulana, R., D. Rachmawati dan S. Anggoro. 2013. Pola osmoregulasi, pertumbuhan dan kelulushidupan keong macan (Babylonia spirata 1) pada media dengan salinitas berbeda. Journal of Management of Aquatic Resources 2(3): 233-242.

Poorten, B.T and C.J. Walters. 2015. How can bioenergetics help us predict changes in fish growth patterns?. Fisheries Research 180: 23-30.

Roy, R. 2013. Budidaya Sidat. Agromedia Pustaka. Jakarta

Saridu, S. A., S. Anggoro dan J. Suprijanto. 2017. Respon osmotik dan pertumbuhan juvenil abalon haliotis asinina pada salinitas media berbeda. Prosiding seminar nasional hasil-hasil penelitian perikanan dan kelautan kevi. FPIK-Pusat Kajian Mitigasi Bencana dan Rehabilitasi Pesisir, Undip, Semarang,716-727. 
Temmy, S. Anggoro dan N. Widyorini. 2017. Tingkat kerja osmotik dan pertumbuhan kerang hijau Perna viridis yang dikultivasi di perairan Tambak Lorok Semarang. Journal of Maquares 6(2): 164-172.

Urbina, M. A and C. N. Glover. 2015. Effect of salinity on osmoregulation, metabolism and nitrogen excretion in the amphidromous fish, inanga (Galaxias maculatus). Journal of Experimental Marine Biology and Ecology $473: 7-15$.

Wirabakti, M. C. 2006. Laju pertumbuhan ikan nila merah (Oreochromis niloticus 1) yang dipelihara pada perairan rawa dengan sistem keramba dan kolam. Journal Tropical Fisheries 1 (1) : 61 - 67.

Yurisma, E.H., N. Abdulgani, dan G. Mahasri. 2013. Pengaruh salinitas yang berbeda terhadap laju konsumsi oksigen ikan gurame (Osprhonemus gouramy) skala laboratorium. Jurnal Sains dan Seni 1(1):1-4. 